\title{
Any Relations between Management of Cash Flows \& Costs of Benefiting from Debits by Separation of Type of Industry among Accepted Companies at Tehran Stock Exchange Organization
}

\author{
Azadeh Paryabi (Corresponding author) \\ Department of Accounting, Islamic Azad University, Shadegan Branch \\ Shadegan, Iran \\ Tel: 98-938-520-7212 E-mail: paryabi_a_com@yahoo.com \\ Alireza Fazlzadeh \\ College of Economics and Management, University of Tabriz \\ University of Tabriz, Tabriz, Iran \\ Tel: 98-914-404-2925 E-mail: fazlzadeh_acc@yahoo.com
}

Received: September 22, 2011

Accepted: December 21, 2011

Published: March 1, 2012

doi:10.5539/ijbm.v7n5p222

URL: http://dx.doi.org/10.5539/ijbm.v7n5p222

\begin{abstract}
The present research intends to provide different information about cash flows management, any effective factors and also the effect of capital structure type on it. It is really important to consider cash situation of company and especially the correctness and true information of operational cash flows. This is because any persons who may benefit from mentioned information would be enabled to apply mentioned information for estimation of time, quantity and ensuring or non-ensuring about future cash flows. Management of cash flows means any consciously functions for changing any reports and/or time table of cash flows which may lead to financial reports and for tricking the users. (Amy L, Geile, 2007)

In this research, we have considered any relations between management of cash flows and any costs for supplying of foreign financial resources (debit costs) within a period of time 2003-2007 in accepted companies in Tehran Stock Exchange Organization. Also there is a difference between financial costs of both companies groups with managed or non-managed cash flows. The type of the capital structure is effective in management of cash flows. It is in a way that management of cash flows is more obvious in those companies with financial resources mainly out of debits amounts. Different parts of cash flow includes changing of accounts receivable, stock of goods, short-term investment and circulating capital or debit costs.
\end{abstract}

Keywords: Managed cash flows, Debit costs, Different parts of cash flows, Government ownership, Company size, Sale growth

\section{Introduction}

Cash is one of the most important \& critical resources in all economic units because it is a sign of public purchase and major item of economic transactions. The effect of measurements is based upon cash flow in the past, present and/or future. Briefly it is possible to say that all financial accidents are related to cash amount. All account subject headings in accounting are related to cash amount in any ways. (Mousavi, Ebrahim, 2004) Cash flow management and conscious selection of transactions are completely for changing of financial reports with the goal of tricking the users and/or creating a positive output of cash flows management. When the companies manage to perform different transactions deliberately which may led to manipulation of cash flows of operations, they would not show the real amounts of money and their real time tabling out of company's functions. Any manipulation of these functions may cause abnormal and non-fixed operational cash functions. (Amy L, Geile, 2007) Management of cash flow is reasonable in accordance with accounting theories of assumptions and any relations among different persons supplying of commercial resources. (Nazemi, A. \& Saghafi, A., 2007) There 
are three assumptions in accounting proving theory as allowance, debit and political costs which are related with management of cash flows and its motivations as follows:[2]

\subsection{Management Allowance theory}

It may estimate that in case of allocating any criteria for manager allowance (like accounting profit), it will try to benefit from accounting methods for increasing its profit and allowances accordingly. There are two methods for finding the goal of allowance, profit and cash flow.

A- Through changing of accounting policy

B- Through controlling or changing of obligatory items and cash flows

\subsection{Liability theory}

The mentioned theory estimates the high rate of debit to companies' capital may make probably the managers to benefit from special accounting methods for increasing the profit. The high rate of debits to capital will be resulted company face with different necessities and conditions in its own debit contracts. In order to receive the loan, loan owner will consider different situations for loan receiver upon which he/she is entitled to receive the loan. Here it is possible for manager to control and/or change obligatory items for obtaining required conditions to receive the loan.

\subsection{Political costs theory}

This theory estimates that in comparison with small companies, great companies may benefit from accounting methods in order to show lower profits. The size and greatness of company is an index for considerable political aspect of it. Therefore we assume that if contractual persons of company know that accounting profit is a sign of exclusive ownership of profit by owner, then such information would be expensive for the company. As a result, if managers feel that they are in center of political attention, they would be motivated to write some other accounting methods to show lower amount of profit. When the managers of companies feel that they are center of political attention, they would try to use profit accounting methods to show their lower cash flows and vice versa. In parallel with mentioned theories in proving theory of Management of cash flows especially for considering of debit theory, this research intends to specify any relation between cash flows management and debit costs.

\section{Literature Review}

The main subject of this research is to study any effects of related factors of capital structure and other effective financial variants on cash flow management.

Frankel (2005) studied any circulating capital reduction which may lead to an increase in operational cash flows. Especially any reduction in current assets and increase in current debits may lead to an increase in operational cash flows.

He noted that there is a considerable reduction in capital and all managers intends to go forward from specified minimum for operational cash flows.

Therefore managers will reduce circulating capital in order to apply relevant goals of operational cash flows. In addition, it may consider any contractual encouragements for manipulation of accounts and show that management of cash flow is more common n companies. Then the subject of "Circulating capital" will be found in allowance contracts of managers and their encouragements. (Pointing out to proved theory of allowance theory). This may show specific proves that show all managers would be encouraged against finding any goals of cash flows and circulating capital. The present paper provides a lot of proves in motivation of managers for manipulation of operational cash flows for obtaining relevant allowance. (Frankel, 2005)

Jiyang (2005) provided some proves about companies which may implement cash flows management for finding positive operational cash flows and obtaining their estimations and relevant dividend and cash goals. In the field of literature history about operational cash flows, he found out that non-abnormal parts of cash flows have lower fixed condition. This is in compliance with non-fixed operational cash flows management with lower quality as well. (Jiang, 2005)

Minton \& Scrand, 1999, found a positive relation between the fluctuations of 3-months operational cash flows and different indexes of foreign financial supply including debit costs. This is a sign of this reality that higher fluctuations of cash flows may cause higher debit costs for companies. They show that companies with lower operational cash flows will have higher cash flows changes. As a result what is important for investors is the 
frequency of cash flows and current interactions between cash flows and further fluctuations. (Minton and Schrand, 1999)

Ali, (1994) considered the importance of cash flows level in a way that any small changes in cash flows may provide more information against incomes. Of course, this is not fixed in those companies with high level of cash flows changes. The results show that investors consider different importance levels for cash flows and based upon the value changes of cash flows. Similarly, holders of negotiable notes are worry about any probable condition of lack of repayment of companies and their ability in interest payment. If there is a low level of operational cash flows, holders of negotiable notes have more worries about company's ability in on-time performance of their obligations. Of course very high level operational cash flows have no more positive effect on holders of negotiable notes because they will not receive any more interests than specified amount in debit contracts. (Ali, 1994)

Through a research made by Jous \& Plasko, 2004, it was revealed that temporary losses are the result of positive cash flows and negative obligatory items. While permanent losses include some great negative cash flows and negative obligations. In case the combined information of cash flows and profit show different scenarios in future, any transaction of managed cash flows and interest level may be effective on credit estimation of creditors of future functions. (Joos \& Plesko, 2004)

There is no more research about cash flows management in country, but due to similar concept of cash flows management with profit management, we will point out to different researches made in this case and cash amounts.

In a paper under the title of "The role of optional contractual items for profit management in accepted companies in Tehran Stock Exchange Organization", Mashayekhi et. al (2006) considered some of the optional contractual items as a factor for management of companies profit especially when the reduction of cash amounts is resulted from weak operation of commercial unit. In other words, any cash amounts resulted from optional contractual will have a converse meaningful relation as well. (Mashayekhi et. al, 2006)

Ashari (2004) investigated any relevant factors of profit management through a research under the title of "Effective factors on profit management among all accepted companies at Singapore Stock Exchange Organization". This research includes four theories for testing of size variants, profitability, industry and nationality on profit management. The results of four mentioned variants show that more profit management is applicable in those companies with little profitability. It means the effect of industry and more interests of high-risks companies (High risks industries) in this case. Nationality is effective on profit management but company's size has no more effects on it. (Ashari, N., Koh, H, Tant, S and Wong W, 1994)

Mohammad Mojdeh (2006) investigated any possible estimation of cash flows through operational profit through his research under the title of any relation between cash flows resulted from operational activities and operational profit. The main question of this research is whether operational profit should be provided for assisting investors for estimation of future cash flows or not? This research is based upon all financial statements of accepted companies at Stock Exchange Organization. This information supplied by the use of stock exchange reports and Arya Sahm Information System and Complete Jame' Software. In order to have theories test of research we used some independent variants (contractual profit, operational income, operational costs) and dependent variant (cash flows resulted from operational activities). We analyzed these variants by the use of multi-variant regression model and by the help of STATISTICA software and concluded that it is possible to approve main theory.

\section{Research Theories}

In this research we have any difference of cash flows of the whole company resulted from normal cash flows as the managed or abnormal cash flows. The main question of research in parallel with this research is: How much is the effect of cash flows management at Tehran Stock Exchange on financial costs of Company? Following are research theories:

\section{First major theory:}

There is a negative meaningful relation between managed cash flows and debit cost (financial costs) based upon the type of industry.

\section{First indirect theory:}

There is a negative meaningful relation between receivable accounts and debit cost (financial costs) based upon the type of industry. 


\section{Second indirect theory:}

There is a negative meaningful relation between short-term investment and debit cost (financial costs) based upon the type of industry.

\section{Third indirect theory:}

There is a negative meaningful relation between changes of stock of goods and debit cost (financial costs) based upon the type of industry.

\section{Fourth indirect theory:}

There is a negative meaningful relation between circulating capital changes and debit cost (financial costs) based upon the type of industry.

\section{Second major theory:}

There is a negative meaningful relation between managed $\&$ non-managed cash flow and debit cost (financial costs) based upon the type of industry.

\section{Population, Sample and Sampling Method}

The population of this study is accepted companies at Tehran Stock Exchange. The financial reports and concerned information about their transactions have been studied within a 5-years period of time from 2003 up to 2007.

For this purpose, we prepared a statistical sample of accepted companies at Tehran Stock Exchange by simple random sampling method. The mentioned sample includes different companies with following conditions:

1) Accepted companies before 2003

2) Companies with the fiscal year ending on 21.March

3) Companies without any violation and /or changes in fiscal period

4) Companies appointed rather than investing and/or financial intermediate.

5) Companies with available data

As a result, totally 41 companies appointed from 2003 to 2007 . The number of samples is 205 companies.

\subsection{Research method}

In this research we intend to study any relation between cash flows management and benefiting from debits in accepted companies at Tehran Stock Exchange. Therefore firstly we used cash flows statements and further effects out of management and manipulation of cash flows from 2003 up to 2007 in order to adjust cash flows statements. At first step and in order to specify any effects of effective variants on total operational and annual cash flows of companies normalized by total annual assets, we used the following function for specifying the effective variants of intervals on cash flows including B1, B2 and B3. By the following methods we may calculate operational cash flows for recognition and measuring of effective factors on it:

$$
\mathrm{OCFt} / \mathrm{TAt}=\beta 0+\beta 1(1 / \mathrm{TAt})+\beta 2(\mathrm{REVt} / \mathrm{TAt})+\beta 2(\triangle \mathrm{REVt} / \mathrm{TAt})+\varepsilon
$$

Where:

$\mathrm{TA}=$ Total assets /year

$\mathrm{OCF}=$ Total of cash flows divided on total assets /year

$\mathrm{REV}=\mathrm{Total}$ of incomes divided on total assets /year

$\triangle \mathrm{REVt}=$ Change of income divided on total assets /year.

Intervals B1, B2 and B3 show the effects of different variants such as total assets, total income and annual income changes on annual operation cash flows. The above-mentioned intervals are calculated for a specified 5 -years period and then it is possible to use above-mentioned intervals for specifying any abnormal and manipulated cash flows. By the use of function 2 is it possible to calculate abnormal cash flows through the following formula:

$$
\text { ABNOCFt } / \text { TAt }=\text { OCFt } / \text { TAt }-\{\beta 1(1 / \text { TAt })+\beta 2(\text { REVt } / \text { TAt })+\beta 3(\triangle \mathrm{REVt} / \mathrm{TAt})\}
$$

$\mathrm{ABNOCF}=$ Abnormal cash flows.

It is necessary to calculate separately abnormal \& manipulated cash flows for each company for a 5-years period. Then we may use the average of ABNOCF variant for the above-mentioned 5-years period as a criterion for 
manipulated cash flows. In second step, we appointed financial costs of company as a criterion for benefiting from long-term financial resources and financial supply of company as the debit costs criterion. In third step and by the use of statistical regression function and unity interval between variants we will specify any relation between ABNCF indexes (independent variant) and dep (Dependant variant) as well. Different parts of cash flow including any change in receivable accounts, stock of goods, circulating capital and short-term investment would be considered in relation to considered debit costs.

Furthermore we should specify the effect of company's size, financial axle, ownership of government and sale growth rate on managed cash flows. In order to find any managed cash flows we may use operational cash flows variants, total of assets and total annual incomes and for finding out debit costs rate it is possible to use total annual financial costs of companies.

\subsection{Statistical methods of research}

Statistical tests of research include unity analysis and multi-form regression among different variants of the research. Also K-S test was used for ensuring about normal data. All required information about companies obtained through data banks of Tadbir Pardaz and Dena Sahm and official site of Tehran Stock Exchange and then Excel software was used for collection and required calculations at wide page. Final analysis made by SPSS software, version 11,5. We benefited from panel analysis for a general consideration and estimation. Type of data nature is the real reason of benefiting this method. This is because of collecting of data on partial- time basis in panel analysis. There is no more independency of observations in any data collected by this method because there are various observations for each company which are related to each other. As it was stated, data are considered in mass situation. Therefore there is a 7-years data for each company. In other words, number of data in this analysis is equal to number of companies multiply in number of the years.

$$
\begin{gathered}
\operatorname{Ln}(\text { Yit })=\beta o+\beta 1 \text { Xit }+\varepsilon i t \\
i=1,2, \ldots, n \\
t=3003, \ldots ., 2007
\end{gathered}
$$

The object is to estimate $\beta o, \beta 1$ by the use of minimum combined squares (PSL). Although the estimation of parameters in this method is different with minimum normal squares (OLS), (observations are separated from each other in minimum squares method while there is no more self-rule in normal minimum squares method). But the obtained indexes have similar description with regression analysis.

\section{The Results of Research Theories Testing of First Major Theory}

For this purpose, we used unity interval and linear regression for considering any relations between abnormal cash flows and financial costs. Probable amount (or meaningful level) of F is equal to 0.00 for this model. Since it is lower than 0.05 , therefore any zero assumption at insurance $=\% 95$ is rejected. It means that there is a meaningful model for this purpose. The statistical t amount for growth rate of assets is 0.001 and lower than 0.05 . Therefore the model is meaningful at insurance level $=\% 95$. This model is as follows:

$$
\text { Depit }=5.02-0.332 \text { ind } 1+0.109 \text { cont } 1+748.9 \text { cont2 }
$$

Therefore there is a direct meaningful relation between abnormal cash flow and financial costs. In addition the size of company and percentage of government ownership are effective on model results.(table\#1)

\subsection{First indirect theory test}

For this purpose, we used unity interval and linear regression for considering any relations between fixed assets growth rate variants and long-term output of shares (average 5 years). Probable amount (or meaningful level) of $\mathrm{F}$ is equal to 0.034 for this model. Since it is lower than 0.05 , therefore any zero assumption at insurance $=\% 95$ is rejected. It means that there is a meaningful model for this purpose. The statistical $t$ amount for growth rate of assets is 0.0 and lower than 0.05 . Therefore the model is meaningful at insurance level $=\% 95$. This model is as follows:

$$
\text { Depit=-0.437ind } 2+523.1 \text { cont } 2
$$

Therefore there is a negative meaningful relation between accounts receivable changes and financial costs. In addition percentage of government ownership is effective on model results.(table\#2)

\subsection{Second indirect theory test}

For this purpose, again we used unity interval and linear regression. Probable amount of $\mathrm{F}$ is equal to 0.00 for this model. Therefore any zero assumption at insurance $=\% 95$ is rejected. It means that there is a meaningful 
model for this purpose. The statistical $t$ amount for growth rate of assets is 0.005 and lower than 0.05 . Therefore research model is as follows:

$$
\text { Depit }=4.53-0.28 \text { ind } 3+793.6 \text { cont } 2
$$

Therefore there is a negative meaningful relation between short-term investment and financial costs. In addition percentage of government ownership is effective on model results.(table\#3)

\subsection{Third indirect theory test}

For this purpose, we used unity interval and linear regression. Probable amount of $\mathrm{F}$ was equal to 0.00 for this model. Therefore any zero assumption at above-mentioned insurance rate is rejected. It means that there is a meaningful model for this purpose. The statistical $t$ amount for growth rate of assets is 0.00 and lower than 0.05 . Therefore research model is as follows:

$$
\text { Depit=1.312- } 0.389 \text { ind } 4+0.107 \text { cont } 1+587.57 \text { cont2 }
$$

Therefore there is a negative meaningful relation between short-term investment and financial costs. In addition percentage of government ownership is effective on model results.(table\#4)

\subsection{Fourth indirect theory test}

For this purpose, we used unity interval and linear regression. Probable amount of $\mathrm{F}$ was equal to 0.00 . Therefore any zero assumption at above-mentioned insurance rate is rejected. It means that there is a meaningful model for this purpose. The statistical $t$ amount for growth rate of assets is 0.026 and lower than 0.05 . Therefore research model is as follows:

$$
\text { Depit }=6.351-0.686 \text { ind } 5+644.4 \text { cont2 }
$$

Therefore there is a negative meaningful relation between short-term investment and financial costs. In addition percentage of government ownership is effective on model results.(table\#5)

\subsection{Second major theory test}

In order to test above-mentioned theory, we used variance analysis test and statistic $\mathrm{F}$ analysis. The probable or meaningful level of this statistic is 0.037 and lower than 0.05 . Therefore any zero assumption at insurance $\% 95$ is rejected. In other words there is a meaningful difference between financial costs in both groups of manages / non-managed cash flows.(table\#6)

\section{Conclusion}

This research intends to consider any relation between abnormal cash flows (managed) and its different parts and financial costs in accepted companies in Tehran Stock Exchange. In fact we consider the role of Cash Flows Management on the structure and combination of financial resources of companies through the relevant financial costs as an index for specifying the benefiting rate of debit financial resources in financial supply. Similarly with a research made by Gili in 2007, the results of this research show that there is a converse relation between abnormal cash flows and its parts with financial costs. In other words, those companies which may benefit from their debits more in their financial resources may face with lower conditions for any further manipulation of cash amounts by managers in order to show a suitable status for company.

\subsection{Proposals based upon theories}

According to the results of researches, it was specified that there is a meaningful and indirect relation between managed cash flows and financial costs at Tehran Stock Exchange Organization. Therefore we present the following proposals based upon the obtained results of the above-mentioned research:

\subsubsection{Some proposals for investors and creditors}

1) Since there is a relation between cash flows management and debit costs, it is concluded that the type of capital structure is effective on cash flows management in order to submit a better image of current \& future cash amounts. Therefore it is proposed to benefit from relevant indexes based upon abnormal cash flows and then manage to invest with more knowledge and clear information about financial situation of companies.

2) Since according to the results of investigation it was specified that there is a relation between different parts of Cash Flows including any changes of accounts receivable, changes in stock of goods, short-term investment and any changes in circulating capital and debit costs, therefore it is expected the company should consider all above-mentioned items in specifying any management of cash flow and when analyzing 
the company's function and current cash situation. Then it is necessary to consider the obtained result as a basic factor in specifying the investment portfolio or supplying any credits.

6.1.2 Proposals for managers

Recognition the real meaning of cash flows management, the effects of its performance on current \& future status of companies and relevant recognition methods which we may propose to managers to consider as well.

\subsection{Some proposal for future researches}

1) In order to control any effects of economic part of industry, it is necessary to perform all considerations on separation method of different industries

2) In order to increase the integration of the research, it is proposed to consider the role of other effective factors on the results such as sale volume, debit rate and financial risk index of company.

3) The effect of other qualitative factors such as economic-political and social conditions in relation with consciously management of cash flows.

4) Considering the management of cash flows in two groups of company with different managements (private \& governmental) and its different dimensions, differences, similarities and creation fields.

5) Any relation of cash flows management with other financial indexes based upon the quality of financial statements like profit management.

\subsection{Research limitations}

In spite of the subject of this research for finding required resources and information, most of researchers may face with some limitations. Also we faced with some limitations such as access limits to information as a general limitation for most of researches and some in the scope of the research as well.

Followings are the mentioned limitations:

1) Lack of access to audited information of companies out of Tehran Stock Exchange Organization. Therefore it is possible only to benefit from relevant information of the accepted companies at Tehran Stock Exchange.

2) Lack of consideration of other probable effective variants on management of cash flows like economic/ political and social conditions

3) In order to make clear research findings, some of the limitations about optional samples have been considered in statistical population of the research.

4) Inflation rate in our country has two digits and in face there are not any standards for adjusting the historical financial statements of companies. High rate of inflation and its further probable consequences on financial information, may damage the results of the researches based upon this type of information.

\section{Resources}

Ali. (1994). Incremental Information Content of Earnings, Working Capital from Operations, and Cash Flows. Journal of Accounting Research, 32 (1994): 61-74. http://dx.doi.org/10.2307/2491387

Amy L, Geile. (2007). Cash Flow management and the cost of debt "a dissertation submitted to the faculty of the committee of business administration. University of Arizona.

Ashari, N., Koh, H, Tant, S and Wong W. (1994). Factors affecting income smoothing among listed companies in Singapore. Accounting Research.

Frankel, (2005). "Managing Reported Operating CF: An Empirical Investigation of 4th Q working capital decreases and benchmark beating" working paper.

Jiang. (2005). "Beating Earnings Benchmarks and the Cost of Debt" working paper Michigan State University.

Joos \& Plesko. (2004). "Valuing Loss Firms" MIT working paper.

Khaki. Statistics \& its application in management. 2, pp 218-219.

Mashayekhi, B, \& Mehrani, S. (2006). The role of obligatory contractual items in profit management of accepted companies at Tehran Stock Exchange. Accounting \& Auditing Considerations, No. 42, pp. 61-74. 
Minton and Schrand. (1999). The impact of cash flow volatility on discretionary investment and the costs of debt and equity financing. The Journal of Financial Economics, 54, 423-460. http://dx.doi.org/10.1016/S0304-405X(99)00042-2

Momeni, M. (2007). Statistical analysis by the use of SPSS. Ketab-e-No publication.

Mousavi, Ebrahim. (2004). Magazine 70 of Auditing Organization.

Nazemi, A., \& Saghafi, A. (2007). Philosophical attitude towards Accounting proving theory. Social \& Human sciences Magazine, Shiraz University, No. 1, pp 55-37.

Taheri, M, R. (1994). A review on Accounting Recognition method. Accounting \& Auditing considerations, Numbers $12 \& 13$, pp 30-5.

Table 1. Coefficients

\begin{tabular}{|l|c|c|c|c|c|}
\hline \multirow{2}{*}{ Model } & \multicolumn{2}{|c|}{ Non-standard interval } & Standard interval & \multirow{2}{*}{ Statistic t } & \multirow{2}{*}{ Meaningful level } \\
\cline { 2 - 4 } & $\beta$ & Standard violation & Beta & & \\
\hline (Constant) & 5.025 & .788 & & 6.380 & .000 \\
\hline Ind1-1 & -.332 & .337 & -.334 & -.879 & .001 \\
\hline Control 1 & .109 & .054 & .083 & 2.032 & .043 \\
\hline Control 2 & 748.903 & 35.553 & .842 & 21.64 & .000 \\
\hline Control 3 & .334 & .195 & .071 & 1.711 & .089 \\
\hline Control 4 & -.054 & .051 & -.041 & -1.059 & .291 \\
\hline
\end{tabular}

a. Dependent Variable: Indep

Ind1: Managed cash flow

Control 1, control 2, control 3, control 4: Company's size, financial axle, government ownership percentage, sale growth

Pearson correlation $=-0.309$

Adjusted R Square $=0.696$

$\mathrm{F}=93.667 \quad \mathrm{Sig}=0.000$

Table 2. Coefficients ${ }^{\mathrm{a}}$

\begin{tabular}{|l|c|c|c|c|c|}
\hline \multirow{2}{*}{ Model } & \multicolumn{2}{|c|}{ Non-standard interval } & Standard interval & Statistic t & \multirow{2}{*}{ Meaningful level } \\
\cline { 2 - 4 } & $\beta$ & Standard violation & Beta & & \\
\hline (Constant) & 1.529 & .811 & & 1.885 & .061 \\
\hline Control 1 & .079 & .044 & .062 & 1.790 & .075 \\
\hline Control 2 & 523.110 & 38.920 & .607 & 13.441 & .000 \\
\hline Control 3 & .225 & .161 & .050 & 1.395 & .165 \\
\hline Control 4 & -.038 & .042 & -.030 & -.911 & .363 \\
\hline Ind2 & -.437 & .453 & -.362 & -8.212 & .000 \\
\hline
\end{tabular}

Ind2: Changes of accounts receivable

Control 1, control2, control 3, control 4: Company's size, financial axle, government ownership percentage, sale growth

Pearson correlation $=-0.760$

Adjusted R Square $=0.783$

$\mathrm{F}=142.802$

Sig $=0.000$ 
Table 3. Coefficients ${ }^{\mathrm{a}}$

\begin{tabular}{|l|c|c|c|c|c|}
\hline \multirow{2}{*}{ Model } & \multicolumn{2}{|c|}{ Non-standard interval } & Standard interval & Statistic t & Meaningful level \\
\cline { 2 - 5 } & $\beta$ & Standard violation & Beta & & \\
\hline (Constant) & 4.530 & 1.155 & & 3.922 & .000 \\
\hline Control 1 & .112 & .081 & .080 & 1.386 & .169 \\
\hline Control 2 & 793.634 & 54.439 & .828 & 14.579 & .000 \\
\hline Control 3 & .409 & .289 & .084 & 1.413 & .161 \\
\hline Control 4 & .026 & .193 & .008 & .133 & .895 \\
\hline Ind3 & -.28 & .50 & -.32 & .563 & .005 \\
\hline
\end{tabular}

a. Dependent Variable: Indep

Ind3:Short-term investment

Pearson correlation $=-0.296$

Adjusted R Square $=0.702$

$\mathrm{F}=51.401$

Sig $=0.000$

Table 4. Coefficients ${ }^{\mathrm{a}}$

\begin{tabular}{|l|c|c|c|c|c|}
\hline \multirow{2}{*}{ Model } & \multicolumn{2}{|c|}{ Non-standard interval } & Standard interval & Statistic t & \multirow{2}{*}{ Meaningful level } \\
\cline { 2 - 4 } & $\beta$ & Standard violation & Beta & & \\
\hline (Constant) & 1.312 & .914 & & 1.436 & .153 \\
\hline Control 1 & .107 & .049 & .082 & 2.195 & .029 \\
\hline Control 2 & 587.577 & 40.263 & .659 & 14.593 & .000 \\
\hline Control 3 & .151 & .180 & .032 & .842 & .401 \\
\hline Control 4 & -.018 & .047 & .014 & -.383 & .702 \\
\hline Ind4 & -.389 & .058 & -.294 & 6.678 & .000 \\
\hline
\end{tabular}

a. Dependent Variable: Indep

Ind4: Changing of stock of goods

Pearson correlation $=-0.678$

Adjusted R Square $=0.751$

$\mathrm{F}=121.154$

Sig $=0.000$

Table 5. Coefficients ${ }^{\mathrm{a}}$

\begin{tabular}{|l|c|c|c|c|c|}
\hline \multirow{2}{*}{ Model } & \multicolumn{2}{|c|}{ Non-standard interval } & Standard interval & Statistic t & \multirow{2}{*}{ Meaningful level } \\
\cline { 2 - 4 } & $\beta$ & Standard violation & Beta & & \\
\hline (Constant) & 6.351 & 1.156 & & 5.494 & .000 \\
\hline Control 1 & -.030 & .064 & -.025 & -.474 & .636 \\
\hline Control 2 & 644.421 & 40.949 & .856 & 15.737 & .000 \\
\hline Control 3 & .213 & .185 & .061 & 1.153 & .251 \\
\hline Control 4 & -.076 & .049 & -.076 & -1.547 & .125 \\
\hline Ind5 & -.686 & .655 & -683 & 1.543 & .026 \\
\hline
\end{tabular}

a. Dependent Variable: Indep

Ind5: Circulating capital

Pearson correlation $=-0.412$

Adjusted R Square $=0757$

$\mathrm{F}=65.637$

Sig $=0.000$

Table 6. Test of Homogeneity of Variances

\begin{tabular}{|c|c|c|c|}
\hline Levene Statistic & Freedom degree 1 & Freedom degree 1 & Meaningful level \\
\hline .065 & 1 & 198 & .799 \\
\hline
\end{tabular}

